\title{
The influence of glycerin on nitrogen removal in wastewater treatment with activated sludge
}

\author{
Joanna Smyk ${ }^{1}$, Katarzyna Ignatowicz ${ }^{1}$ \\ ${ }^{1}$ Bialystok University of Technology, Faculty of Civil and Environmental Engineering, Department \\ of Technology in Engineering and Environmental Protection, Wiejska 45E, 15-351 Białystok
}

\begin{abstract}
The paper presents the efficiency of nitrogen removal from wastewater using glycerin as an external carbon source. The study was conducted during the municipal wastewater treatment process in two independent activated sludge chambers of SBR type. One of the chambers contained glycerol as the source of easily available organic compounds. The study showed that the use of glycerol as the external carbon source resulted in a higher efficiency of nitrogen removal in compare with the reactor without external carbon source.
\end{abstract}

\section{Introduction}

These sources are divided into internal (present in wastewater), endogenous (produced in the activated sludge chambers due to biomass decomposition), and external (not present in the wastewater)[1]. Internal sources refer to the organic carbon substrates obtained both in the inlet wastewater (as the organic load of entering wastewater) or generated and stored in cells, also known as an endogenous carbon source[2].

Delivery of external carbon sources to treated wastewater often becomes necessary to achieve high efficiency of sewage treatment, which must meet very stringent requirements for reducing the concentration of nitrogen. One of the initial stages of the activities related to the possibility of using the alternative sources carbon for the denitrification process is a review of available waste products and semi-finished products from different branches of the food industry in terms of the high $\mathrm{COD} / \mathrm{N}$ ratio and high content of easily degradable organic compounds. Mainly the post-production wastewater from distillery, brewery, fishing industry, as well as waste and semi-finished products such as corn syrup, glucose, molasses, beet pulp, raw spirit or fusel oil, are taken into account $[1,3,4,5,6]$.

Another waste product, which has a great potential as an external carbon source is the glycerol fraction, which is a byproduct of biodiesel production. There are numerous reports of the glycerol use as a carbon source suitable for the wastewater treatment process[7, 8, 9, $10]$,as well as on the use of glycerol to reduce the biomass production [11]. Nowadays, in many countries, diesel oil is supplemented with biodiesel causing a gradual increase of its production, and thereby the amount of waste glycerol fraction $[12,13]$.At about 10 liters of produced biodiesel, about 1 liter glycerol is generated [14, 15].Glycerol phase, besides glycerol (propane-1,2,3-triol) - 50-60\%, contains other substances in its composition such as methanol, mono-, diacylglycerols, free fatty acids and soaps [16].Due to the fact that glycerol originated from biodiesel production has many impurities, therefore it has led to 
a concomitant decrease in the price of glycerol along with an increase in its production. Consequently, glycerol has become a waste, which should be neutralized, and price for this product is more attractive as compared to other substrates used as external carbon sources in the denitrification and phosphorus removal processes[17, 18, 19,20,21].

The study aimed at demonstrating that the use of glycerol as an external carbon source in wastewater treatment process has a positive impact on the effectiveness of the removal of nitrogen forms from wastewater and can replace other alternative carbon sources.

\section{Methods}

The study was conducted during the municipal wastewater treatment process in two independent SBR-activated sludge reactors. The active capacity was $10 \mathrm{dm}^{3}$, including $6.5 \mathrm{dm}^{3}$ was the activated sludge provided by the sewage treatment plant in Białystok, while the remaining quantity originated from the raw mechanically treated wastewater $\left(3.5 \mathrm{dm}^{3}\right)$ that were also obtained from the sewage treatment plant in Białystok.

The single cycle of the reactor lasted for 6 hours and included following phases: sewage supply (2 min), mixing (anaerobic) (60 min), aeration (3.5hrs), sedimentation $(1 \mathrm{~h})$, and decantation $(0.5 \mathrm{~h})$. During the aeration phase, the compressed air was fed through the diffuser placed at the bottom of the rector; depending on the operating phase, the amount of air was from 0.1 to $3.0 \mathrm{mg} \mathrm{O} / \mathrm{dm}^{3}$, concentration of activated sludge $3.5 \mathrm{~kg} / \mathrm{m}^{3}$, sludge index oscillated within $120-150 \mathrm{~cm}^{3} / \mathrm{g}$, hydraulic load of the chamber was $1.4 \mathrm{~m}^{3} / \mathrm{m}^{3} \mathrm{~d}$, whereas the pollution load $0.2 \mathrm{~kg} \mathrm{COD} / \mathrm{m}^{3} \mathrm{~d}$. Glycerin, as a source of easily available organic compounds, in an amount of $100 \mathrm{mg} / \mathrm{dm}^{3}$ wastewater was added into one of the chambers in each cycle, twenty minutes after the sewage pouring.

The collected sewage samples were filtered immediately after the filtration. Each filtrate was subject to determination of the following items in accordance with applicable methodology $[2,4,5,3,22]$ :

- COD $_{\mathrm{Cr}}$ - dichromate PN-74/C-04578.03,

- $\mathrm{BOD}_{5}-$ manometric applyingOxiTop Standard system,

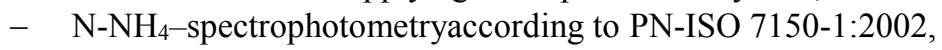

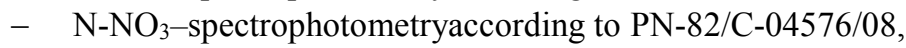

- Ntot. -spectrophotometryaccording to PN-EN ISO 6878:2006,

- $\quad$ Ptot. -spectrophotometryaccording to PN-EN ISO 6878:2006.

\section{Results and Discussion}

The results of the R1 reactor wastewater tests without the addition of an external carbon source were included in Table 1, while Table 2 shows the results of wastewater tests from R2 reactor with addition of glycerin as external carbon source. Figure 1 shows the concentration of studied nitrogen forms after individual stages of wastewater treatment. 
Table 1.Data and test results of wastewater without addition of glycerin as an external carbon source

\begin{tabular}{|c|c|c|c|c|c|c|c|}
\hline \multicolumn{8}{|c|}{ REACTOR R1 -without carbon source } \\
\hline & 1 & 2 & 3 & 4 & 5 & 6 & 7 \\
\hline & 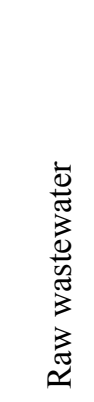 & 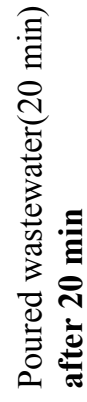 & 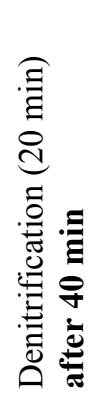 & 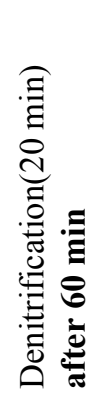 & 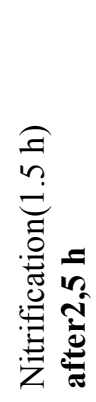 & 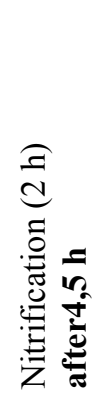 & 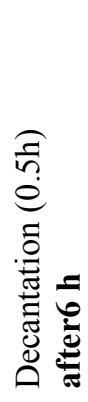 \\
\hline $\mathrm{COD}\left[\mathrm{mgO}_{2} / \mathrm{dm}^{3}\right]$ & 530 & 268 & 262 & 259 & 254 & 243 & 35 \\
\hline $\mathrm{BOD}_{5}\left[\mathrm{mgO}_{2} / \mathrm{dm}^{3}\right]$ & 230 & 25 & 20 & 20 & 15 & 8 & 6 \\
\hline Total nitrogen $\left[\mathrm{mgN} / \mathrm{dm}^{3}\right]$ & 118.0 & 84.0 & 68.7 & 55.2 & 48.1 & 24.3 & 14.4 \\
\hline Nitrate $\mathrm{NO}_{3}{ }^{-}\left[\mathrm{mgN} / \mathrm{dm}^{3}\right]$ & 2.6 & 3.9 & 2.4 & 3.6 & 4.6 & 8.6 & 8.6 \\
\hline Ammonia $\mathrm{NH}_{4}^{+}\left[\mathrm{mgN} / \mathrm{dm}^{3}\right]$ & 51.1 & 58.2 & 55.3 & 41.6 & 33.5 & 9.7 & 1.8 \\
\hline Phosphate $\mathrm{PO}_{4}\left[\mathrm{mgP} / \mathrm{dm}^{3}\right]$ & 18.5 & 15.2 & 18 & 12.8 & 1.5 & 1.1 & 0.8 \\
\hline
\end{tabular}

Table 2. Data and test results of wastewater with addition of glycerin as an external carbon source

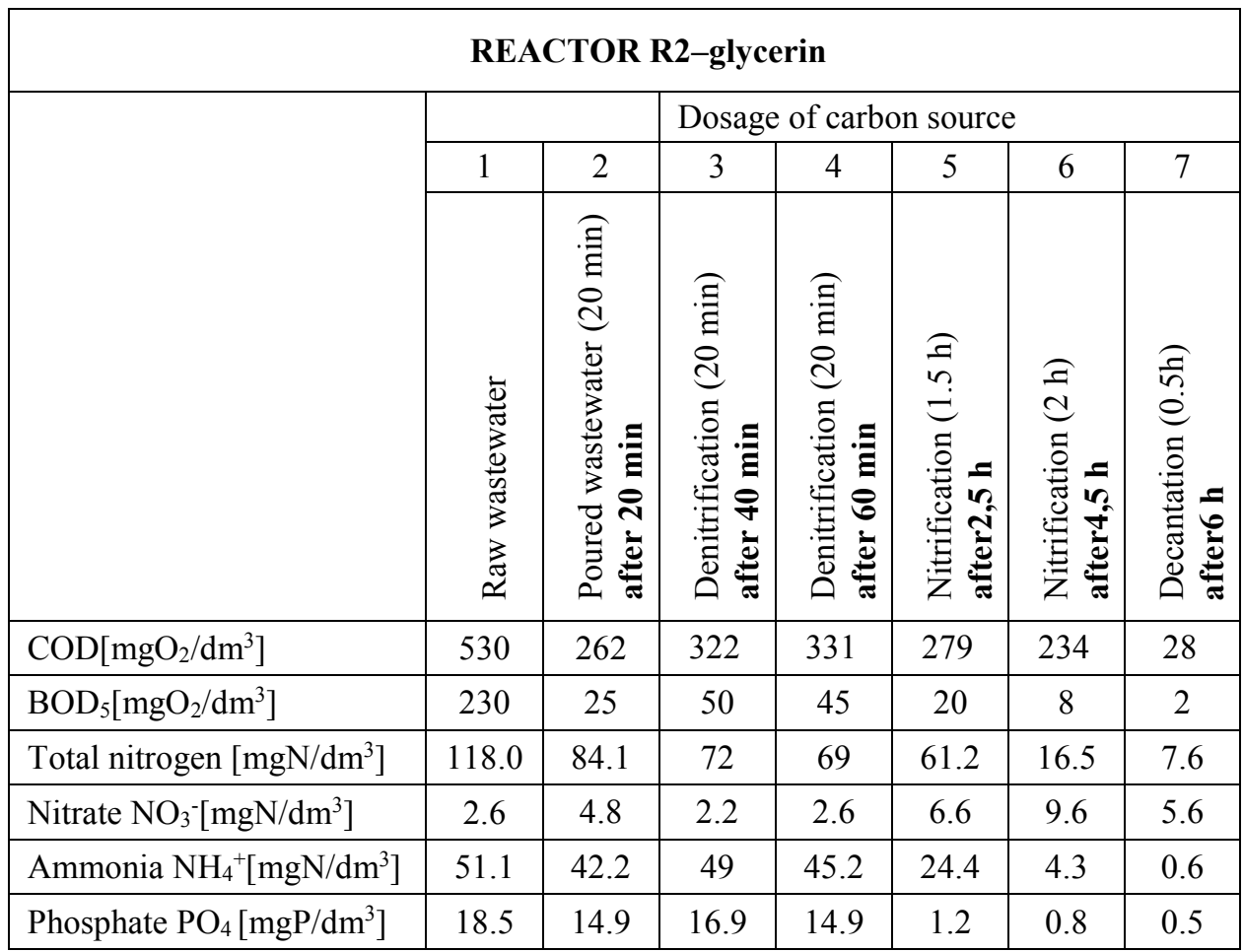




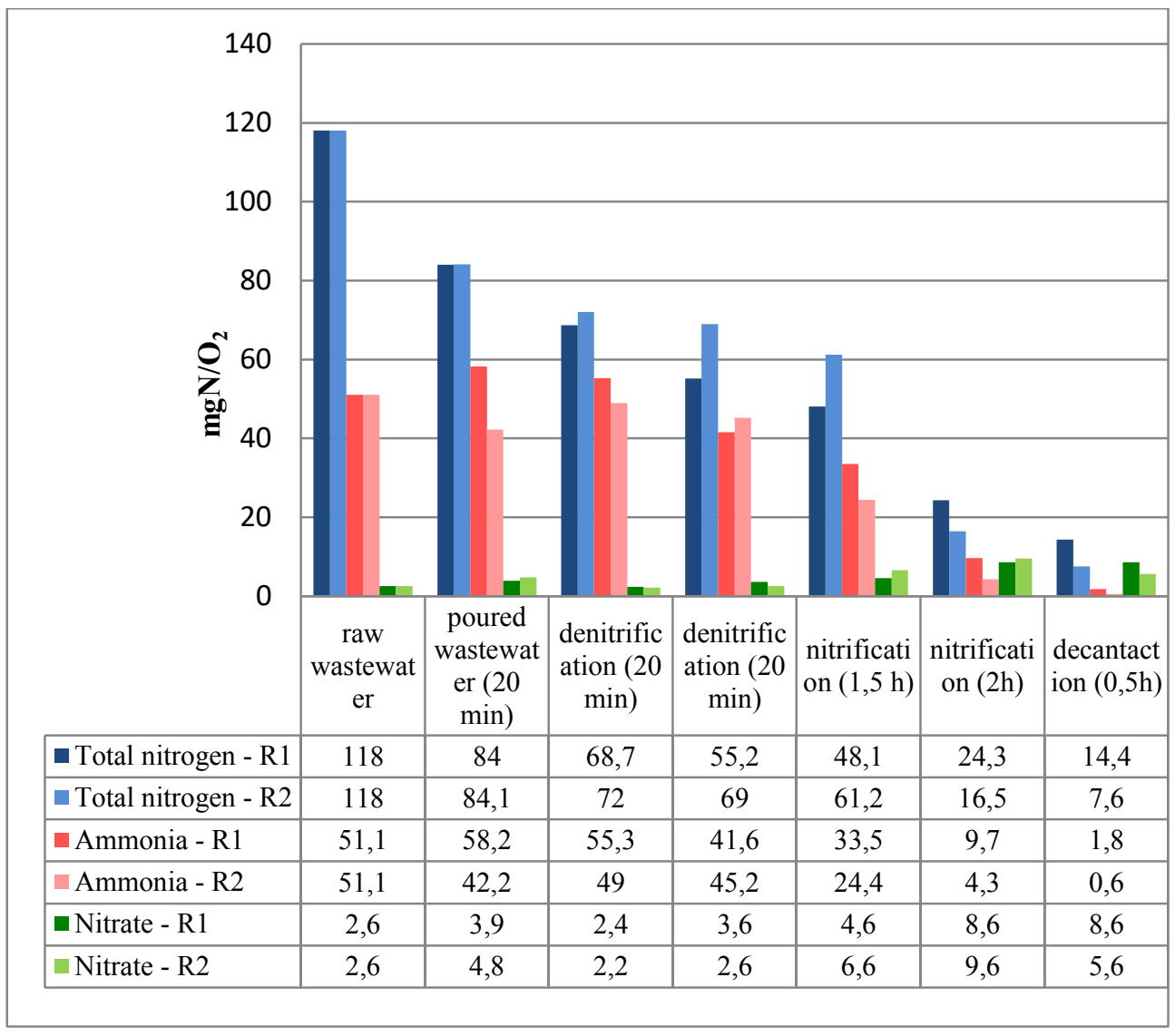

Fig. 1.Concentrations of tested nitrogen forms after individual phases of wastewater treatment

Studies performed byBernatet al. [12] upon the use of glycerin as an external carbon source in the process of nitrogen removal in SBR-type chambers revealed that the optimum $\mathrm{COD} / \mathrm{N}$ ratio should amount to 3.0, at which both nitrates removal and biomass production from SBR chambersis the lowest. The $\mathrm{COD} / \mathrm{N}$ ratio in tested raw wastewater was 4.49 , while just before glycerin addition, this $\mathrm{COD} / \mathrm{N}$ decreased to 3.11 , thus close to recommended by above authors.

Value of COD in raw wastewater amounted to $530 \mathrm{mgO}_{2} / \mathrm{dm}^{3}$, while $\mathrm{BOD}_{5} 230$ $\mathrm{mgO}_{2} / \mathrm{dm}^{3}$. Concentration of the total nitrogen in raw sewage was $118 \mathrm{mgN} / \mathrm{dm}^{3}$, ammonia $51.5 \mathrm{mgN} / \mathrm{dm}^{3}$ and nitrate $2.6 \mathrm{mgN} / \mathrm{dm}^{3}$.

Twenty minutes after the reactors filling, some decrease in COD and $\mathrm{BOD}_{5}$ values were observed -available carbon source were taken by denitrification bacteria. Value of COD in reactor $\mathrm{R} 1$ was $268.0 \mathrm{mgO}_{2} / \mathrm{dm}^{3}$, while value of $\mathrm{BOD}_{5} 25.0 \mathrm{mgO} \mathrm{O}_{2} / \mathrm{dm}^{3}$. In the reactor R2, similar levels were recorded: COD262.0mgO $2 / \mathrm{dm}^{3}, \mathrm{BOD}_{5} 25 \mathrm{mgO} / \mathrm{dm}^{3}$. In both reactors, ammonia concentrations were similar-in reactorR $184.0 \mathrm{mgN} / \mathrm{dm}^{3}$, while in reactor $\mathrm{R} 284.1 \mathrm{mgN} / \mathrm{dm}^{3}$. Content of nitrates in both reactors increased up to 3.9 $\mathrm{mgN} / \mathrm{dm}^{3}$ in $\mathrm{R} 1$ and to $4.8 \mathrm{mgN} / \mathrm{dm}^{3}$ in $\mathrm{R} 2$. The increase in the ammonia concentration was also recorded in R1 to $58.2 \mathrm{mgN} / \mathrm{dm}^{3}$, whereas decrease in R2 amounted to $42.2 \mathrm{mgN} / \mathrm{dm}^{3}$.

Then glycerin as the external carbon source was added into the reactor R2 and after 20 minutes of denitrification process, subsequent samples were collected. In R1 reactor, where the wastewater treatment process proceeded without support of the external carbon source, a further slight decrease in COD $\left(262 \mathrm{mgO}_{2} / \mathrm{dm}^{3}\right)$ and $\mathrm{BOD}_{5}\left(20 \mathrm{mgO}_{2} / \mathrm{dm}^{3}\right)$ was 
noted. Introducing the carbon source in a form of glycerin caused the increase in COD value in reactor $\mathrm{R} 2$ by $60.0 \mathrm{mgO}_{2} / \mathrm{dm}^{3}$ up to $322.0 \mathrm{mgO}_{2} / \mathrm{dm}^{3}$. The $\mathrm{BOD}_{5}$ value in reactor $\mathrm{R} 2$ increased to $50 \mathrm{mgO}_{2} / \mathrm{dm}^{3}$. Some decrease in the total nitrogen concentration in both reactors was recorded: in R1 $68.7 \mathrm{mgN} / \mathrm{dm}^{3}$, while in $\mathrm{R} 272.0 \mathrm{mgN} / \mathrm{dm}^{3}$. In the case of nitrate, there were also lower concentrations as compared to the previous control point. In reactor R1, nitrate content was $2.4 \mathrm{mgN} / \mathrm{dm}^{3}$, in reactorR $2.4 \mathrm{mgN} / \mathrm{dm}^{3}$. Concentration of ammonia slightly decreased in $\mathrm{R} 1$ to $55.3 \mathrm{mgN} / \mathrm{dm}^{3}$, whereas in reactor R2 the adverse situation was recorded-there was an increase in ammonia up to $49.0 \mathrm{mgN} / \mathrm{dm}^{3}$, however the concentration was still lower than in reactor R1.

After subsequent 20 minutes of anaerobic process of wastewater treatment, further slight decrease in COD in reactor R1 was found $\left(259 \mathrm{mgO}_{2} / \mathrm{dm}^{3}\right)$; Value of $\mathrm{BOD}_{5}$ remained intact $\left(20 \mathrm{mgO}_{2} / \mathrm{dm}^{3}\right)$. In the reactor with glycerin addition, an opposite situation was observed-there was further COD increase by $9 \mathrm{mgO}_{2} / \mathrm{dm}^{3}$ to the level of $322 \mathrm{mgO}_{2} / \mathrm{dm}^{3}$. The $\mathrm{BOD}_{5}$ value decreased to $45 \mathrm{mgO}_{2} / \mathrm{dm}^{3}$, but these results were higher than in reactor without carbon source addition. Concentration of the total nitrogen still decreased reaching $55.2 \mathrm{mgN} / \mathrm{dm}^{3}$ in reactor R1. For R2 reactor with addition of glycerin, the total nitrogen concentration was higher than in reactor $\mathrm{R} 1$ and amounted to $69.0 \mathrm{mgN} / \mathrm{dm}^{3}$ giving the difference of $13.8 \mathrm{mgN} / \mathrm{dm}^{3}$ total nitrogen between both reactors. In both reactors, an increase in nitrates contents to $3.6 \mathrm{mgN} / \mathrm{dm}^{3}$ was recorded in $\mathrm{R} 1$ and $2.6 \mathrm{mgN} / \mathrm{dm}^{3}$ in R2. The ammonia level decreased in R1 to $41.6 \mathrm{mgN} / \mathrm{dm}^{3}$, while in $\mathrm{R} 2$ to $45,2 \mathrm{mgN} / \mathrm{dm}^{3}$. Difference of the ammonia concentrations at that control point between reactor without carbon source R1 and with glycerin R2 amounted to $3.6 \mathrm{mgN} / \mathrm{dm}^{3}$.

Another samples were collected after 1.5 hours of wastewater aeration. Value of COD in reactor R1 was $254 \mathrm{mgO}_{2} / \mathrm{dm}^{3}$, while $\mathrm{BOD}_{5} 15 \mathrm{mgO}_{2} / \mathrm{dm}^{3}$. In reactor R2, despite of decreased COD value by $52 \mathrm{mgO} / \mathrm{dm}^{3}$ to the level of $279 \mathrm{mgO}_{2} / \mathrm{dm}^{3}$ and value of $\mathrm{BOD}_{5}$ by $15 \mathrm{mgO}_{2} / \mathrm{dm}^{3}$ to $20 \mathrm{mgO}_{2} / \mathrm{dm}^{3}$, these numbers were higher than in the reactor without glycerin addition. Also total nitrogen concentration was lower in reactor without carbon source amounting in reactor $\mathrm{R} 1$ to $48.1 \mathrm{mgN} / \mathrm{dm}^{3}$. In the case of reactor R2, concentration of the total nitrogen was $61.2 \mathrm{mgN} / \mathrm{dm}^{3}$. Difference between total nitrogen levels between reactors $\mathrm{R} 1$ and $\mathrm{R} 2$ was $13.1 \mathrm{mgN} / \mathrm{dm}^{3}$. Concentration of nitrates in $\mathrm{R} 1$ increased up to 4.6 $\mathrm{mgN} / \mathrm{dm}^{3}$, which resulted from the inhibition of denitrification process due to the supply of oxygen into reactors. In reactor R2,also increase in nitrates concentration was recorded, but these were higher values-even as high as $6.6 \mathrm{mgN} / \mathrm{dm}^{3}$. Content of ammonia decreased in reactor $\mathrm{R} 1$ to $33.5 \mathrm{mgN} / \mathrm{dm}^{3}$, whereas in $\mathrm{R} 2$ to $24.4 \mathrm{mgN} / \mathrm{dm}^{3}$. Difference in the ammonia concentrations at that control point between reactor without carbon source (R1) and that with glycerin (R2) amounted to $9.1 \mathrm{mgN} / \mathrm{dm}^{3}$

Subsequent samples were collected after another 2 hoursof wastewater aeration. Value of COD in reactor R1 was $243.0 \mathrm{mgO}_{2} / \mathrm{dm}^{3}$. In reactor with glycerin, there was further intake of available organic compounds, which resulted in lower COD values (234.0 $\mathrm{mgO}_{2} / \mathrm{dm}^{3}$ )than in reactor without carbon source addition. In the case of $\mathrm{BOD}_{5}$ in both reactors, the same values were recorded $-8.0 \mathrm{mgO}_{2} / \mathrm{dm}^{3}$. Concentration of the total nitrogen in reactor R1 was determined as $24.3 \mathrm{mgN} / \mathrm{dm}^{3}$. For reactor $\mathrm{R} 2$, concentration of total nitrogen was $16.5 \mathrm{mgN} / \mathrm{dm}^{3}$. Difference in the total nitrogen between both reactors amounted to $7.8 \mathrm{mgN} / \mathrm{dm}^{3}$. Nitrate concentration in both reactors increased -in R1 to $8.6 \mathrm{mgN} / \mathrm{dm}^{3}$, while in $\mathrm{R} 2$ to $9.6 \mathrm{mgN} / \mathrm{dm}^{3}$. A long duration of wastewater aeration resulted in a significant lowering the ammonia concentration in both reactors as compared to the previous control point. In R1, concentration of this nitrogen form was $9.7 \mathrm{mgN} / \mathrm{dm}^{3}$, while in $\mathrm{R} 24.3 \mathrm{mgN} / \mathrm{dm}^{3}$. Difference in the ammonia content between reactor without carbon source R1 and that with glycerin R2 was $5.4 \mathrm{mgN} / \mathrm{dm}^{3}$.

Value of CODin treated wastewater from reactor $\mathrm{R} 1$ after decantation process amounted to $35.0 \mathrm{mgO}_{2} / \mathrm{dm}^{3}$, while value of $\mathrm{BOD}_{5}$ was $6.0 \mathrm{mgO}_{2} / \mathrm{dm}^{3}$. Despite of adding the 
external carbon source, the COD value in treated sewage with glycerin addition amounted to $28.0 \mathrm{mgO}_{2} / \mathrm{dm}^{3}$, and $\mathrm{BOD}_{5} 2.0 \mathrm{mgO}_{2} / \mathrm{dm}^{3}$. These are lower numbers than in reactor $\mathrm{R} 1$, where no additional carbon source was used. Concentration of the total nitrogen in treated wastewater from reactor R1 amounted to $14.4 \mathrm{mgN} / \mathrm{dm}^{3}$, ammonia $1.8 \mathrm{mgN} / \mathrm{dm}^{3}$, and nitrates $8.6 \mathrm{mgN} / \mathrm{dm}^{3}$. Treatment of wastewater in reactor R1 caused the removal of total nitrogen in $87.8 \%$ and ammonia in $96.5 \%$. In the case of reactor with glycerin addition, concentration of the total nitrogen in treated wastewater was $7.6 \mathrm{mgN} / \mathrm{dm}^{3}$, ammonia $0.6 \mathrm{mgN} / \mathrm{dm}^{3}$ and nitrate $5.6 \mathrm{mgN} / \mathrm{dm}^{3}$. Treating the sewage in reactor $\mathrm{R} 2$ resulted in the removal of total nitrogen in $93.6 \%$, while ammonia in $98.8 \%$. The use of glycerin in R2 reactor has resulted in a higher efficiency of the wastewater treatment process than in R1 reactor, where no external carbon source was applied. Despite of the increase in the final nitrate concentration in reactors $\mathrm{R} 1$ and $\mathrm{R} 2$, the reactor with external carbon source addition contained lower nitrate concentration by $3.4 \mathrm{mgN} / \mathrm{dm}^{3}$.

Like in the research by Bodiket al. [8], in which results from laboratory and technical scale tests upon the use of glycerin fraction in denitrification process in SBR-type chambers, were presented, No elevated COD concentrations were recorded in the outflow indicating a properly adjusted glycerin dose and its utilization during denitrification process.

\section{Conclusions}

1. The use of glycerin as an external source of carbon during wastewater treatment has resulted in a higher removal efficiency of nitrogen forms than in reactor where no external carbon source has been applied along with low COD content in the purified wastewater.

2. Despite of the increase in nitrate concentration in sewage treated in both reactors, the use of glycerin has resulted in a decrease in the concentration of nitrates in purified wastewater by $3.4 \mathrm{mgN} / \mathrm{dm}^{3}$ as compared to reactor without supply the external carbon source.

3. Glycerin as a waste product can provide better alternative to other expensive sources of carbon.

\section{References}

1. J. Mąkinia, K. Czerwionka, J. Drewnowski, M. Swinarski, M. Chrzanowska, W. Fordoński, For. Ekspl., 2, 15-20 (2008).

2. W. Styka, P. Beńko, G., W. i Tech. San., 9, 21-24 (2007).

3. E. Kalinowska, For. Ekspl., 5, 16-17 (2006).

4. E. Kalinowska,For. Ekspl., 3, 41-42 (2006).

5. M. Kaszubowska, J. Majtacz, J. Mąkinia, K. Czerwionka, E. Kulbat, Zesz. Nauk.. Inż. Śr., 141, 78-86 (2011).

6. J. Mąkinia, K. Czerwonka, Guidance for the assessment of alternative sources of coal. Innovative source Coal Support for denitrification in municipal wastewater treatment plants. The project financed by the European Regional Development Fund under the Operational Programme Innovative Economy(in Polish, 2013).

7. Bodik, A. Mlstakova, S. Sedlacek, M., Biores. Technol., 100, 2452-2456(2009).

8. Grabinska-Loniewska, T. Slomczynski, Z. Kanska, Wat. Res., 19, 1471-1477(1985).

9. J.C. Akunna, C. Bizeaua, R. Moletta, Wat. Res., 27, 1303-1312 (1993).

10. J.A. Torà, J.A. Baeza, J. Carrera, J.A. Oleszkiewicz, Chem. Eng. J., 172, 994-998 (2011). 
11. D. Kulikowska, K. Bernat, Biores.Tech., 142, 297-303 (2013).

12. K. Bernat, D. Kulikowska, K.Żuchniewski, Chem. Eng. J., 267,324-331 (2015).

13. G.P. da Silva, M. Mack, J. Contiero, Biotech. Adv., 27, 30-39(2009).

14. D.T. Johnson, K.A. Taconi, Env. Progr., 26, 338-348 (2007).

15. J. Guerrero, C. Tayà, , A. Guisasola, J. A. Baeza, Wat. Res., 46,2983-2991 (2012).

16. Melcer, E. Klugmann-Radziemska, A. Ciunel, Arch. Gosp. Odpad. i Ochr. Śr., ] 13, 1-20(2011).

17. S.S. Yazdani, R. Gonzales,Curr. Op. in Biotech., 18,213-219 (2007).

18. Escapa, M.F. Manuel, A. Morant, X. Gomez, S.R. Guiot, B. Tartakovsky, Ener. and Fuels, 23,4612-4618 (2009).

19. W. Janczukowicz, J. Rodziewicz,Źródła węgla w procesach biologicznego usuwania związów azotu i fosforu, (Monografie Komitetu Inżynierii Środowiska Polskiej Akademii Nauk, 114, Lublin 2013).

20. K. Ignatowicz, J. Piekarski, D. Kozłowski,Rocz. Ochr. Śr., 17, 1178-1195 (2015).

21. P. Kogut, J. Piekarski, K. Ignatowicz, Rocz. Ochr. Śr., 16, 534-545 (2014).

22. W. Dąbrowski, R. Żyłka, P. Malinowski, Envir.Res., 153 (2017)

The project was financed by the Ministry of Science and Higher Education (S/WBiIS/3/2014 and W/WBiIS/9/2016). 